\title{
REMARKS ON AN OLD VOCABULARY FROM TRINIDAD
}

BY

THOMAS E. PENARD

In 1871 Daniel G. Brinton ${ }^{1}$ ) gave an account of the Arawak language of Guiana, based on the study of a manuscript of Theodore Shultz in the Library of the American Philosophical Society at Philadelphia. The distinguished American ethnologist compared the language of the Guiana Indians with that spoken in the Antilles as recorded in the works of early explorers, and pointed to Trinidad as the original home of the Surinam Arawaks.

He said:

"The Arawaks of today when asked concerning their origin point to the north, and claim at some not very remote time to have lived at Kairi, an island, by which generic name they mean Trinidad. This tradition is in a measure proved correct by the narrative of Sir Walter Raleigh, who found them living there in 1595 , and by the Belgian explorers who in 1598 collected a short vocabulary of their tongue. This oldest monument of the language has sufficient interest to deserve copying and comparing with the modern dialect."

The vocabulary of sixteen words which Brinton compared with the dialect of about a century ago was taken from Johannes de Laet's Novus Orbis, published in 1633. He expressed astonishment in finding such close agreement between the old and modern terms, saying:

"When it is remembered that the dialect of Trinidad no doubt differed slightly from that of the mainland; that

1) D. G. Brinton, The Arawack Language of Guiana in its Linguistic and Ethnological Relations, Philadelphia, 1871. 
the modern orthography is German and that of De Laet's list is Dutch; and that two centuries have intervened between the first and the second, it is really a matter of surprise to discover such a close similarity.'

Evidently Brinton had overlooked an earlier vocabulary collected in Trinidad by Robert Dudley, and appended to the narrative of his voyage published by Richard Hakluyt ${ }^{\mathbf{1}}$ ). According to this narrative Dudley was in Trinidad from 1 February to 12 March, 1595, departing only a few days before the arrival of Sir Walter Raleigh at that island.

Since Dudley's vocabulary is not only older but also more extensive than de Laet's, it is interesting to compare the words preserved by him with those of modern Arawak. Fortunately I am able to make use of a manuscript vocabulary of that language, collected in Dutch Guiana by my brothers and myself since the year 1900, thus more than three centuries after Dudley's visit to Trinidad.

Dudley's list contains 69 words, including a few short phrases. A comparison with modern Arawak is given in the following table. Words from Dudley's vocabulary are spelled as in the original; words from the manuscript referred to above are in accordance with the system of orthography (phonetic) outlined by C. H, de Goeje in his Etudes Linguistiques Caraibes, 1909.

For several words I have been unable to find current equivalents. The majority, however, agree remarkably well with modern Arawak of Surinam, establishing beyond question the fact that in 1595 at least some of the inhabitants of Trinidad were Arawaks. Dudley calls the islanders Simerones. He says of their enemies, the Caribs, "The Caribes I learned to be man-eaters or Canibals, and great enemies to the islanders of Trinidad".

In many instances the discrepancy between definitions

1) A voyage of the honourable Gentlemen M. Robert Duddeley, now knight, to the isle of Trinidad, and the coast of Paria. Written at the request of M. Richard Hakluyt. In: Principal navigations, voyages, traffiques and discoveries of the English Nation, London, 1598-1600. 
given by Dudley and the meaning today is readily explained as the result of a misunderstanding of just what object was to be named. Wishing to know the word for "toe", the questioner may actually have pointed to the toenail which was correctly given by the Indian as $d a$ bodda, "my toenail". The following are obviously examples of this class: desereth, "an eye" = my nose; daria, "the gummes" = my teeth; desire, "the lips" = my nose; dacabbo, "the palme of the hand" = my hand; dadena, "the wrist" = my arm; daddano, "the calfe of the legge" $=$ my leg; and weevah, "the heaven" = star. The syllable "da" = my, prefixed to words for the parts of the body, as has since been the case, was not appreciated by Dudley

The term Guttemock, denoting "man", is probably identical with Otomaca, an Orinoco tribe, of which Crevaux published a short vocabulary in the Bibliothèque linguistique americaine, tom. viii, p. 262, and Uttumaku, mentioned by Schumann in his Arawakisch-Deutsches Wörterbuch, under the word paletti. Judging from the words recorded by Crevaux, the Otomacos were neither Carib nor Arawak. Raleigh in the narrative of his first voyage speaks of a place at the mouth of the Orinoco called Hororotomaka, apparently from hororo, land and Otomaka, the name of the tribe referred to by Schumann and Crevaux.

We find a number of post-Columbian words, viz., tolletillero, bells; mointiman, iron; arkeano and arguecona, scissors; addehegaeno, mirror; perota, silver; casparo, sword; yeddola, knife; sambolers, hat; some of which as perota (Sp. plata), casparo, and yeddola have a wide distribution. For two of these, tolletillero and mointiman I find no allied forms. Tolletillero is apparently an onomatopœic word.

Arkeano (or arguecona) scissors, finds a counterpart in Surinam in arekekona, from alükan or arükan, to cut and kona, thumb or thing. Nordenskiöld ${ }^{1}$ ) (pp. 108-110) has

1) E. Nordenskiöld, Comparative ethnological studies 5; Deductions suggested by the geographical distribution of some post-Columbian words used by the Indians of S. America, Göteborg, 1922. 
no term like it in his table of words for scissors, unless the Aparai and Oyana erachi (ex Crevaux) is related to it. Addehegaeno, mirror, is found in Surinam in the form adekhekona, or dogökwana, from adeken, to see, and kona thumb or thing. It seems to me that these words for scissors and mirror, occurring nowhere else but in old Trinidad and in Guiana, confirm in no small degree the tradition of relationship between the Trinidad and Surinam Arawaks, alluded to by Brinton.

Comparison of words collected by Robert Dudley in Trinidad in 1595 with the modern Arawak dialect of Surinam.

\begin{tabular}{|c|c|c|}
\hline $\begin{array}{l}\text { Arawak } \\
1595\end{array}$ & $\begin{array}{l}\text { Definitions given } \\
\text { by Dudley }\end{array}$ & Modern Arawak of Surinam (Penard M.S.) \\
\hline Guttemock & A man & wadili; loko (man in general). \\
\hline $\begin{array}{l}\text { Tabairo, } \\
\text { Dabarah, } \\
\text { Or Dabarra }\end{array}$ & $\begin{array}{l}\text { The heare of } \\
\text { ones head }\end{array}$ & dabala, dabara, my ear. \\
\hline Dessie & The forehead & dasi, my head; sibaroko, forehead. \\
\hline $\begin{array}{l}\text { Dasereth, } \\
\text { or Dacosi }\end{array}$ & An eye & dasiri, my nose; dakosi, my eye. \\
\hline Dalacoack & The mouth & daleroko, my mouth. \\
\hline Archeh & The teeth & arihi, tooth. \\
\hline Daria & The gummes & dari, my tooth; dari-siroko, my gums. \\
\hline Desive & The lips & dasiri, my nose; reroko-üda, lips. \\
\hline Dill & The tongue & daye, diyeh, my tongue; tala, chin. \\
\hline Dudica & The eares & dadikĕ, my ear. \\
\hline Dacan & A hand & dakhabo, my hand. \\
\hline Dacabbo & $\begin{array}{l}\text { The palme of } \\
\text { the hand }\end{array}$ & dakhabo, my hand; khabrokoh, palm. \\
\hline Dadena & The wrist & $\begin{array}{l}\text { dadenha, dadhüna, my arm; khabo- } \\
\text { andakha, wrist. }\end{array}$ \\
\hline Dacurle & A knee & dakolo, my knee. \\
\hline Daddano & $\begin{array}{l}\text { The calfe of the } \\
\text { legge }\end{array}$ & dadana, my leg; bitunaha, calf of the leg. \\
\hline Dabodda & The toes & $\begin{array}{l}\text { dabada, my nail (of toe or finger); kotihi- } \\
\text { übira, the toes. }\end{array}$ \\
\hline Dacutti & The feete & dakoti, my feet. \\
\hline Cattie & The moone & katsi, katši. \\
\hline Tauraroth & A rope & těme; mibi. \\
\hline Arkeano & $\begin{array}{l}\text { A paire of } \\
\text { cizers }\end{array}$ & $\begin{array}{l}\text { arekekonah, lökökwana, from alükan, to } \\
\text { cut, and kona, thing. }\end{array}$ \\
\hline $\begin{array}{l}\text { Weevah } \\
\text { Harowa }\end{array}$ & $\begin{array}{l}\text { The heaven } \\
\text { A stone good } \\
\text { for the head }\end{array}$ & wiwa, star. \\
\hline
\end{tabular}




\begin{tabular}{|c|c|c|}
\hline $\begin{array}{l}\text { Arawak } \\
1595\end{array}$ & $\begin{array}{l}\text { Definitions given } \\
\text { by Dudley }\end{array}$ & Modern Arawak of Surinam (Penard M.S.) \\
\hline Mointiman & Yron or steele & siparali. \\
\hline Howa & $\begin{array}{l}\text { Munkeis in } \\
\text { generall }\end{array}$ & $\begin{array}{l}\text { howa, huwa, horowe, names for certain } \\
\text { monkeys. }\end{array}$ \\
\hline Carotta & $\begin{array}{l}\text { A thing like } \\
\text { pappe }\end{array}$ & \\
\hline Sakel & $\begin{array}{l}\text { It is well, or I } \\
\text { am well. }\end{array}$ & sakwada, I am well. \\
\hline Techir & A bracelet & ? dikehe, ear ornament. \\
\hline Bodah & A boxe or chest & $\begin{array}{l}\text { bodale, cassava-pan; dosu, from Dutch } \\
\text { "doos". }\end{array}$ \\
\hline Mentinie & A tree & $\begin{array}{l}\text { ? manikinya, banana-plant; ada, adaya, } \\
\text { tree. }\end{array}$ \\
\hline Addehegaeno & A glasse & $\begin{array}{l}\text { adekhe-konaha, dogö-kwana, from adeken, } \\
\text { to see, and kona, thing. }\end{array}$ \\
\hline Calcouri & Gold & kalokoli, copper. \\
\hline Perota & Silver & pelata, from Spanish "plata". \\
\hline Tacorao & A green stone & \\
\hline $\begin{array}{l}\text { Arrara } \\
\text { Caulpiri }\end{array}$ & $\begin{array}{l}\text { Copper } \\
\text { A white stone }\end{array}$ & kalokoli. \\
\hline Casparo & A sword & kasipara, cutlass. \\
\hline Marrahabo & A bow & simala-abo, simalahau. \\
\hline Tibetebe & Cockles & \\
\hline Semaro & An arrow & simara. \\
\hline Huculle & A bow-string & simalau-tšereme. \\
\hline Halete & A potato roote & halitsi, halithe. \\
\hline Caerwoda & A sweete root & ? karowada, "wild Bromelia". \\
\hline Maurisse & Wheat & marisi, corn. \\
\hline Queca & A basket & kiwēke, keke. \\
\hline Yeddola & A knife & yadawala, yadowala. \\
\hline Beyou & A pipe & ? beyoga, bamboo flute; paipa, pipe. \\
\hline Sabolers & A hat & sambeleru (from Spanish). \\
\hline Callit & Bread & kali, khale. \\
\hline Oronuie & Water & oni. \\
\hline Arguecona & $\begin{array}{l}\text { A paire of } \\
\text { cizers }\end{array}$ & areke-konaha, lökö-kwana. \\
\hline Heldaro & A spoone & halaro, calabash spoon. \\
\hline Hemachugh & $\begin{array}{l}\text { A bread which } \\
\text { they eate }\end{array}$ & \\
\hline Hicket & Fire & $h i k i, i k h i$. \\
\hline Ureit & Tabacco & yuli, yuri. \\
\hline Walrowa & A parrot & warara, macaw (Ara ararauna). \\
\hline Barudda & A combe & barüda, bareda, balida. \\
\hline Addoth & A sticke & $a d a$, wood. \\
\hline Barrennaire & $\begin{array}{l}\text { A button, or } \\
\text { beads }\end{array}$ & $\begin{array}{l}\text { knopo, button (from Dutch); kasoro, } \\
\text { yedihi, beads; bala, hair. }\end{array}$ \\
\hline $\begin{array}{l}\text { Curaballa \& } \\
\text { Sibath }\end{array}$ & $\begin{array}{l}\text { for } 2 \text { sundry } \\
\text { stones }\end{array}$ & siba, stone. \\
\hline Tolletillero & Bels & kampana (from Spanish). \\
\hline
\end{tabular}




\begin{tabular}{|c|c|c|}
\hline $\begin{array}{l}\text { Arawak } \\
1595\end{array}$ & $\begin{array}{l}\text { Definitions given } \\
\text { by Dudley }\end{array}$ & Modern Arawak of Surinam (Penard M.S.) \\
\hline Ullasso & A Tuny fish & $\begin{array}{l}\text { koraso, a certain fish which the negroes } \\
\text { call kodokoe. }\end{array}$ \\
\hline Bohery & A flying fish & bohori, bat. \\
\hline Bara & water & bala, sea; oni, water. \\
\hline Haddalle & The Sunne & hadali. \\
\hline $\begin{array}{l}\text { Babage- } \\
\text { Canoaseen }\end{array}$ & $\begin{array}{l}\text { The manner of } \\
\text { the Indians } \\
\text { hailing a ship }\end{array}$ & \\
\hline $\begin{array}{l}\text { Non yuo, } \\
\text { or Non quapa }\end{array}$ & $\begin{array}{l}\text { I know not, or } \\
\text { I cannot tell. }\end{array}$ & meitsinda, I do not know. \\
\hline
\end{tabular}

